\title{
Medico-Legal Evaluation of Geriatric Patients and Mortality Predictors in the Elderly with Forensic Trauma
}

\author{
Geriatrik Hastaların Mediko-Legal Açıdan Değerlendirilmesi Ve Adli \\ Travmalı Yaşlılarda Mortalite Prediktörleri
}

\author{
$\underline{\text { Seda Dağar }}{ }^{1}, \underline{\text { Emine Akınc1 Emektar }}{ }^{1}, \underline{\text { Seref Kerem Corbacioğlu }}{ }^{1}, \underline{\text { Hüseyin Uzunosmanoğlu }}{ }^{1}, \underline{\text { Ozge }}$ \\ Oztekin $^{1}$, Yunsur Cevik ${ }^{1}$
}

${ }^{1}$ Department of Emergency Department, Keçiören Training and Research Hospital, Ankara, Turkey

\begin{abstract}
Objectives: The aim of this study was to investigate demographic and epidemiological aspects of older people with forensic events and to determine factors affecting in-hospital mortality in geriatric patients with forensic trauma.

Materials and Methods: All patients aged $\geq 65$ years who were admitted to the emergency department between January 1, 2015 and January 1, 2018 and reported as a forensic case were included in the study. The demographic data, vital and clinical findings, forensic diagnoses and in-hospital mortality statuses of the patients were recorded. 'Glasgow Coma Scale' for all patients and 'Injury Severity Score' for patients with forensic trauma were calculated. Characteristics of patients with in-hospital mortality and surviving patients were compared. Also, a multivariate logistic regression analyses was used to assess the predictors for in-hospital mortality in patients with forensic trauma.

Results: A total of 598 geriatric forensic patients were included in the analyses. The most frequent forensic admission reason was motor vehicle collisions $(n=317,53.01 \%) .3 .17 \%(n=19)$ of the patients died. The multivariate logistic regression model was formed with age, gender, Injury Severity Score, presence of multitrauma, falling from height and ground level falls. Falling from height was found to be the most distinctive predictor for in-hospital mortality [odds ratio: 54.628], and as age increased, mortality increased as well.

Conclusion: The most frequent forensic event in the older people was motor vehicle collisions. In forensic admissions, the trauma mechanism of falling from height clearly increases in-hospital mortality among the geriatric population.

Keywords: Emergency department, forensic medicine, geriatrics, mortality, trauma
\end{abstract}

\section{Öz}

Amaç: Çalışmanın amacı acil servise başvuran geriatrik yaş grubu adli vakaların demografik ve epidemiyolojik açıdan irdelenmesi ve geriatrik adli travma olgularında hastane içi mortalite üzerine etki eden faktörlerin belirlenmesidir.

Materyal ve Metot: Çalışmamıza, 1 Ocak 2015 ve 1 Ocak 2018 tarihleri arasında acil servise başvuran ve adli bildirim yapılan 65 yaş ve üzeri tüm hastalar dahil edildi. Hastaların demografik verileri, vital ve klinik bulguları, adli tanıları ve hastane-içi mortalite durumları kaydedildi. Çalışmadaki tüm hastalar için 'Glaskow Koma Skoru' ve adli travmalı hastalar için ek olarak 'Yaralanma Ciddiyet Puanı' hesaplandı. Mortal seyreden ve sağ kalan hastaların özellikleri karşılaştırıldı. Adli travmalı hastalarda hastane içi mortalite prediktörlerini değerlendirmek için çok değişkenli lojistik regresyon analizi kullanıldı.

Bulgular: Çalışmaya toplam 598 geriatrik adli hasta alındı. En sık adli başvuru nedeni motorlu taşıt kazaları ( $\mathrm{n}=317, \% 53,01)$ idi. Hastaların \%3,17'si ( $\mathrm{n}=19)$ öldü. Çok değişkenli lojistik regresyon modeli yaş, cinsiyet, 'Yaralanma Ciddiyet Puanı', multitravma varlığı, yüksekten düşme ve zemin seviyesinden düşme parametreleri ile oluşturuldu. Hastane içi mortaliteyi ön görmede yüksekten düşme en belirgin prediktör olarak bulunurken [OR: 54,628], yaş artıkça mortalite artmaktaydı.

Sonuç: Çalışmamız sonuçlarına göre aktif sosyal hayata katılımı gün geçtikçe artan geriatrik yaş grubunun günümüzde en sık karşılaştı̆̆ adli olay motorlu taşıt kazalarıdır. Ayrıca, adli başvurularda, özellikle yüksekten düşme travma mekanizması geriatrik populasyonda hastane içi mortaliteyi belirgin şekilde arttırmaktadır.

Anahtar Kelimeler: Acil servis, adli tıp, geriatri, mortalite, travma 
Yazışma Adresi / Correspondence:

Seda Dağar

e-posta: sedadagar@gmail.com

Geliş Tarihi: 12.10 .2019

Kabul Tarihi: 14.11.2019

\section{Introduction}

World Health Organization (WHO) emphasizes that the world population is rapidly ageing and that this process has accelerated in the recent years compared to earlier. It is estimated that the increase in the geriatric population will double between 2015 and 2050, and the proportion of this age group will become more than $20 \%{ }^{1}$. The most distinctive effect of this process on healthcare systems is the increase in older patient admissions to hospitals. ${ }^{2,3}$ Older patient groups are evaluated as a "specialized population" in medicine due to psychosocial and physical aspects of the ageing process. This situation forms one of the most important limitations in the management of older people by preventing the generalization of many data in the literature regarding this age group. ${ }^{4}$

Although forensic cases can be observed in all age groups, both physical and mental disabilities increase the possibility of exposure in the ageing population. ${ }^{2,5}$ Slowing of the mental processes and decline of the extremity coordination contributes to occurrence of trauma, whereas the decrease of self-care related to physical and psychological limitations and inability to protect oneself can prepare the ground for abuse and poisoning. ${ }^{6-8}$ Moreover, comorbid diseases and decline in the physiological reserves in older population make the reflections of forensic processes on this patient group more complicated. ${ }^{9,10}$ Despite this, there are limited publications in the literature regarding forensic cases in older people. ${ }^{3,5,10,11}$ Additionally, as far as we know, there is no study evaluating factors affecting the prognosis in older population with forensic traumas.

The aim of this study was to investigate demographic and epidemiological aspects of older people with forensic events and to determine factors affecting in-hospital mortality in those with forensic trauma.

\section{Material and Methods}

\section{Study design and setting}

Our study was conducted in a tertiary care emergency department (ED) with approximately 250.000 patient admissions per year. Prior to the study, the protocol was approved by the local ethics committee (Kecioren Training and Research Hospital Ethics Committee, 2012-KAEK15/1673). All patients aged $\geq 65$ years who were admitted to the ED between January 1, 2015 and January 1, 2018 and reported as a forensic case were included in the study. In our country, conditions which cause physical and mental health deterioration (firearms, explosives, penetrating injuries, abuse, traffic accidents, assaults, falls and work accidents, drug or food associated poisonings, burns, electric and lightning strikes, asphyxia, torture and suicide attempts) are included in the definition of forensic events, and the healthcare professionals are obliged to inform the nearest competent authority in accordance with the relevant legislation (Turkish Penal Code Article: 280). The demographic data, vital and clinical findings, forensic diagnoses, and inhospital mortality statuses of the patients were acquired by retrospective review of the hospital information system, patient files, and official forensic reports. Patients with missing data were excluded from the study. In the study, 'Glasgow Coma Scale (GCS)' for all patients and additionally 'Injury Severity Score (ISS)' for patients with forensic trauma were calculated by the researchers. Patients with an ISS of 1-8 points were accepted as patients with minor trauma, 9- 
15 points were accepted as patients with moderate trauma, and $\geq 16$ points were accepted as patients with severe trauma.

\section{Statistical analysis}

The analysis of the data acquired throughout the study was performed by the use of IBM SPSS16.0 (Chicago, IL, USA) statistics program. Whether the distribution of discrete and continuous numerical variables was compatible with the normal distribution was analyzed with Kolmogorov-Smirnov test. Because the data were not compatible with normal distributions, they were shown as median values, and interquartile range (IQR, 25\%-75\%) and the categorical variables were shown as the number of cases and percentages $(\%)$. The categorical variables were evaluated with Chi-square test, whereas the continuous variables were evaluated with MannWhitney U test. A univariate logistic regression model was formed in order to estimate the inhospital mortality. After each independent variable was tested in the univariate model, statistically significant $(\mathrm{p}<0.2)$ variables were included in the multivariate logistic regression model.

Multivariate regression model compatibility was evaluated using Hosmer-Lemeshow test, and the results were accepted as statistically significant for $\mathrm{p}<0.05$.

\section{Results}

During the study period, a total number of 8463 forensic admission records were obtained with $612(7.23 \%)$ being in the older age group. Further, 14 patients were excluded from the study because of missing data, and a total of 598 patients were included in the study for statistical analyses. Of these, 330 patients were men $(55.18 \%)$, and median age of the all patients was 71 (IQR, 25\%-75\%; 68-78). The most prevalently observed comorbid disease among the patients was hypertension $(28.92 \%)$. Although the most frequent admission reason for patients with trauma was motor vehicle collisions (MVCs), most frequent non-trauma forensic admission reason was carbon monoxide (CO) poisoning. Additionally, 3.17\% $(n=19)$ of the patients died in the ED or intensive care unit. Demographic data of all forensic patients were shown in Table-1.

Table 1. Demographic data of all forensic patients

\begin{tabular}{|l|c|}
\hline $\begin{array}{l}\text { Sex } n(\%) \\
\text { Male }\end{array}$ & $330(55.18 \%)$ \\
\hline Age median (IQR 25-75) & $71(68-78)$ \\
\hline Comorbidity $n(\%)$ & $173(28.92 \%)$ \\
Hypertension & $100(16.72 \%)$ \\
Diabetes mellitus & $26(4.34 \%)$ \\
COPD & $98(16.38 \%)$ \\
CAD & $21(3.51 \%)$ \\
Chronic kidney disease & $112(18.72 \%)$ \\
Others & $134(120-137)$ \\
\hline Vital signs median (IQR 25-75) & $80(77-83)$ \\
SBP mm/Hg & $75(70-80)$ \\
DBP mm/Hg & $13(12-18)$ \\
HR /min & $97.64(93.32-100)$ \\
RR /min & $15(3-15)$ \\
MAP mm/Hg & $1(1-4)$ \\
\hline GCS median (min-max) & $466(91.19 \%)$ \\
\hline ISS median (IQR 25-75) & $20(3.91 \%)$ \\
\hline ISS groups $n$ (\%) & $25(4.89 \%)$ \\
Mild & \\
Moderate & \\
Severe & \\
\hline
\end{tabular}




\begin{tabular}{|l|c|}
\hline Forensic diagnosis $n(\%)$ & $598(100 \%)$ \\
MVCs & $317(53.01 \%)$ \\
Assaults & $127(21.23 \%)$ \\
CO poisonings & $58(9.69 \%)$ \\
Intoxications/suicides & $29(4.84 \%)$ \\
Falls & $42(7.02 \%)$ \\
Falls from height & $20(3.34 \%)$ \\
Ground level falls & $22(3.67 \%)$ \\
Stabbing injuries & $7(1.17 \%)$ \\
Gunshot injuries & $5(0.83 \%)$ \\
Others & $13(2.17 \%)$ \\
\hline Lesion locations in trauma patients $n(\%)$ & $221(43.24 \%)$ \\
No lesion & $121(23.67 \%)$ \\
Head/neck/face & $23(4.50 \%)$ \\
Thorax & $14(2.73 \%)$ \\
Abdomen/pelvis & $146(28.57 \%)$ \\
Extremity & $107(20.93 \%)$ \\
\hline Multitrauma $n$ (\%) & $69(11.53 \%)$ \\
\hline Patients with life-threatening conditions $n(\%)$ & \\
\hline In-hospital mortality $n$ (\%) & $579(96.82 \%)$ \\
Survivors & $19(3.17 \%)$ \\
\hline Non-survivors & . \\
\hline
\end{tabular}

(COPD: Chronic obstructive pulmonary disease, CAD: Coronary arterial disease, SBP: Systolic blood pressure, DBP: Diastolic blood pressure, HR: Heart rate, RR: Respiratory rate, MAP: Mean artery pressure, GCS: Glaskow coma scale, ISS: Injury severity score, MVCs: Motor vehicle collisions, CO: Carbon monoxide)

Although $94.73 \%(n=18)$ of the forensic patients with in-hospital mortality were trauma patients, 1 patient died due to medication consumed for suicidal purposes. The most frequent mechanism in forensic patients with mortality secondary to trauma was falling from height $(55.55 \%, n=10)$, and this was followed by out-of-vehicle traffic accident and ground level falls. When the characteristics of patients with in-hospital mortality and surviving patients were compared, statistically significant differences were found for GCS, ISS, head/thorax/abdomen/pelvis/extremity injuries, and presence of multitrauma. (Table-2).

A multivariate regression model was formed with age, gender, ISS, presence of multitrauma, falling from height and ground level falls out of the trauma mechanisms of patients with mortality, which were statistically significant. GCS was not included in the model because of a statistically significant and strong correlation with ISS. The model's fitness was evaluated using the Hosmer-Lemeshow test $(\mathrm{p}=0.792)$. Falling from height was found to be the most distinctive predictor for in-hospital mortality [odds ratio (OR), 54.628], and as age increased, mortality increased as well. (Table-3).

\section{Discussion}

This study led to three important conclusions. Firstly, we found that MVCs formed more than half of all forensic events in older people. Although the first reason that comes to mind is the recent extreme increase in the ageing population, we believe that the older people today are more active in social life compared to their peers in previous decades due to medico-social developments. Secondly, we determined that the most frequent non-trauma mechanism in older forensic cases was CO poisoning. This result may be a reflection of the high prevalence of CO poisoning in Turkey, especially during winter months. Moreover, we believe that older people's 
need for increased supervision is not adequately met in society, and this may be another factor causing this result. Finally, we found that the most distinctive predictor for in-hospital mortality in forensic trauma cases was the mechanism of falling from height. Considering that falling from height is one of the high energy trauma mechanisms, this is not a surprising result. However, we believe that the most important factor causing this result is the decrease of compensatory abilities due to physiological regression in older people.

Table 2. Patients characteristics according to mortality in forensic trauma patients

\begin{tabular}{|c|c|c|c|}
\hline & $\begin{array}{c}\text { Survivors } \\
(\mathrm{n}=493)\end{array}$ & $\begin{array}{l}\text { Non-survivors } \\
(n=18)\end{array}$ & $\mathrm{p}$ \\
\hline Age median (IQR 25-75\%) & $71(68-77)$ & $77(68-84)$ & 0.119 \\
\hline $\begin{array}{l}\text { Sex } n(\%) \\
\text { Male }\end{array}$ & $275(55.78 \%)$ & $12(66.66 \%)$ & 0.478 \\
\hline SBP median (IQR 25-75\%) & $134(120-137)$ & $120(90-137)$ & 0.148 \\
\hline DBP median (IQR 25-75\%) & $80(77-83)$ & $80(40-82)$ & 0.313 \\
\hline HR median (IQR 25-75\%) & $73(70-80)$ & $71(50-80)$ & 0.258 \\
\hline $\mathbf{R R}$ median (IQR 25-75\%) & $12(12-18)$ & $16(8-18)$ & 0.772 \\
\hline GCS* median (IQR 25-75\%) & $15(10-15)$ & $3(3-13)$ & $<0.001$ \\
\hline ISS median (IQR 25-75\%) & $1(1-4)$ & $14(10-21)$ & $<0.001$ \\
\hline MAP median (IQR 25-75\%) & $96.62(93-100)$ & $93.54(68.72-100)$ & 0.267 \\
\hline $\begin{array}{l}\text { Lesion locations } \\
\text { Head/neck/face* } \\
\text { Thorax* } \\
\text { Abdomen/pelvis* } \\
\text { Extremity* }\end{array}$ & $\begin{array}{c}110(22.31 \%) \\
15(3.04 \%) \\
9(1.82 \%) \\
137(27.78 \%) \\
\end{array}$ & $\begin{array}{c}11(61.11 \%) \\
8(44.44 \%) \\
5(27.77 \%) \\
9(50 \%) \\
\end{array}$ & 0.004 \\
\hline Multitrauma* & $87(17.64 \%)$ & $12(66.66 \%)$ & $<0.001$ \\
\hline $\begin{array}{l}\text { Comorbidity } \\
\text { Hypertension* } \\
\text { Diabetes mellitus* } \\
\text { CAD* } \\
\text { Chronic kidney disease* }\end{array}$ & $\begin{array}{c}148(30.02 \%) \\
84(17.3 \%) \\
79(16.02 \%) \\
17(3.44 \%) \\
\end{array}$ & $\begin{array}{c}3(16.66 \%) \\
2(11.11 \%) \\
1(5.55 \%) \\
1(5.55 \%) \\
\end{array}$ & $\begin{array}{l}0.221 \\
0.756 \\
0.338 \\
0.483 \\
\end{array}$ \\
\hline
\end{tabular}

*Fisher exact test was used.

(SBP: Systolic blood pressure, DBP: Diastolic blood pressure, HR: Heart rate, RR: Respiratory rate, GCS: Glaskow coma scale, ISS: Injury severity score, MAP: Mean artery pressure, CAD: Coronary arterial disease)

Ageing population ratio and average lifetime has been showing a continuous increase in the last decades. Additionally, older people who need to completely pull away from social life at earlier ages, now show more attendance to active life with improvements in the healthcare services and developments in the management of chronic diseases. ${ }^{6,12}$ We believe that this causes the older population, whose ability to adapt to social life decreases, to be more frequently exposed to forensic events that are a part of the social life compared to the past. Compatible with this argument, it was reported in a study conducted in 2005 that $4.2 \%$ of all forensic cases were in the older age group; this rate was found to be higher $(7.23 \%)$ in our study..$^{10}$ As a result of the older people's shift towards a more active lifestyle, the etiological reasons of both forensic cases and traumas have shown a change through time. In previous decades, the most frequent forensic admission and trauma reason in this age group was falling at home, whereas now-a-days, besides falling outside of home, MVCs have reached a considerable rate varying between $25 \%$ and 
$46 \% \cdot{ }^{2,3,12,13}$ Older adult driver ratio in deadly traffic accidents is reported as $14 \%$ in the literature. ${ }^{14}$ We found the most frequent forensic admission reason as MVCs in our study. This result supports the argument that older people are more included into the daily life process outside of their home compared to the past. Moreover, besides the possible vision and hearing disorders of older drivers and pedestrians, inability to appropriately show secondary reflex responses with slowing down of mental and physical processes may be one of the other possible reasons for the frequent exposure to MVCs.

Table 3. Multivariate regression model to predict in-hospital mortality in forensic trauma patients

\begin{tabular}{|l|c|c|c|}
\hline & Wald & p value & Odds Ratio (95\%CI) \\
\hline Age & 6.165 & 0.013 & $1.136(1.027-1.256)$ \\
\hline Sex & 0.308 & 0.579 & $1.518(0.347-6.642)$ \\
\hline Falls from height & 25.307 & $<0.001$ & $54.628(11.495-259.61)$ \\
\hline Ground level falls & 6.730 & 0.009 & $11.239(1.067-1.204)$ \\
\hline ISS & 16.094 & $<0.001$ & $1.148(1.807-69.91)$ \\
\hline Mutitrauma & 3.570 & 0.059 & $4.093(0.949-17.65)$ \\
\hline
\end{tabular}

(ISS: Injury severity score)

Ageing population is not only vulnerable to trauma but also to non-trauma forensic events. ${ }^{4}$ Psychological and mental evaluation abilities of older people get disrupted due to dementia processes and multiple chronic diseases. ${ }^{5}$ In our study, we found that the most frequent reason for non-traumatic forensic admission was poisoning. $\mathrm{CO}$ is seen as the most frequent poisoning factor with a rate of $9.69 \%$, and we believe that the most probable reason for this result is that older patients are incapable of sensing danger or protecting themselves from danger. The poisoning cases besides $\mathrm{CO}$ observed in our study may have developed due to uncontrolled use of medication, prescribed for multiple comorbid diseases, as a result of a regression in cortical processing. In the literature, it is reported that depression with suicidal attempts are easily observed as a result of the decline of self-respect in older population. ${ }^{15,16}$ The suicide attempts via medication due to the ease of access to comorbidity medications already being used in this age group, may be one of the possible mechanisms of poisonings besides CO. Providing supervision to older people showing significant decline in both mental and psychological adequacy with respect to access to medication may prevent these types of poisonings.

Older people are accepted as more fragile against similar traumas compared to young people. ${ }^{6,17,18}$ Liability to orthopedic injuries due to osteoporosis, increased complication risk due to existing comorbid diseases, delays in wound healing secondary to chronic diseases, such as diabetes mellitus, and impaired response to trauma from the simplest to the most complex one due to physiological reserves assumed to decrease in different amounts with age, have been reported as mortality and morbidity reasons in the literature. ${ }^{3,19}$ In the study by Ferrera et al. ISS, GCS, existence of shock or sepsis, and head trauma have been reported as mortality indicators. ${ }^{13}$ Giannoudis et al. associated development of medical complications, severe head-neck injury, and advanced age (>75 years) with poor prognosis. ${ }^{20}$ Çevik et al. reported ISS, the existence of head trauma and abdominopelvic trauma as important in-hospital mortality predictors. ${ }^{21}$ In our study, we found a significant difference between older patients with and without mortality for GCS, ISS, head trauma, trauma to three body cavities (thorax, abdomen, and pelvis), and extremity trauma along with the existence of multi-trauma. The most important parameter we determined in predicting in-hospital mortality for this age group was falling from height. It is an expected result for older patients who can have severe problems during posttraumatic processes, even with minor traumas affecting a small part of the body, to be affected at a lethal level by a high energy 
trauma pattern that may affect all organ systems. However, we believe that the key here is disruption of compensation mechanisms by physiological regression and the resulting inadequate systemic response given to trauma by ageing.

Comorbidity generates an important obstacle in all medical fields for the ageing population. ${ }^{6}$ However, in the literature, contradictory results have been reported regarding the effects of comorbid diseases on mortality in older trauma cases. In some studies, it is emphasized that preexisting comorbidities have no distinctive effect on the course of this patient group, whereas in other studies, it is stated that they accompany increased mortality in injuries with minor-tomoderate severity. ${ }^{13,22,23}$ In the study by Clement et al., it was reported that comorbidity increases the risk of death after minor trauma by 5.5 times in patients aged $>50$ years. ${ }^{23}$ In our study population, we found that the comorbid diseases (hypertension, diabetes mellitus, coronary artery diseases, and chronic kidney failure) did not have a significant contribution to in-hospital mortality. These varying results in the literature may be due to the fact that older patients with comorbidity have varying physiological reserves independent from their age and care status. Similarly, the fact that the study populations have different severity or stages of comorbid diseases can be shown as another possible reason.

Our study has some limitations. Firstly, because it is a single-center study, our results cannot be generalized to all centers. Secondly, due to its retrospective nature, incomplete and wrong data in the hospital information system may have affected the study results. Because of the same reason, we also could not reach all the parameters for trauma scores except 'ISS'. Additionally, doctors usually provide a forensic report after a forensic statement. Hence, the patients may have provided wrong information on purpose or unintentionally, and therefore, there may be missing or extra forensic records. Finally, we believe that having a small number of patients with mortality for medical and traumatic reasons is the main limitation of our study. This may have affected our results especially the ones of logistic regression.

In conclusion, we determined that the most frequently encountered forensic event by older people, whose involvement in the daily life is increasing day-by-day, was MVCs. In forensic admissions, the trauma mechanism of falling from height clearly increases in-hospital mortality among older adults. In view of these results, consideration of increased supervision needs of ageing population may be effective in prevention of forensic cases and consideration of increased care needs may be effective in prevention of poor prognosis.

Declaration of conflicting interests: The authors declared no potential conflicts of interest with respect to the research, authorship, and/or publication of this article.

\section{References}

1. Steverson M. Ageing and health. World Health Organization, Fact Sheets. 2018, pp 1-7. Available from URL: http://www.who.int/news-room/fact-sheets/detail/ageing-and-health. (Access Date: 10.09.2018).

2. Kandiş H, Karakuş A, Katırcı Y, Karapolat S, Kara İH. Geriatric population and forensic traumas. Turk J Geriatr 2011;14(3):193-8.

3. Mert E. Use of emergency departments by elderly patients. Turk J Geriatr 2006;9(2):70-4.

4. Hruska K, Ruge T. The tragically hip: trauma in elderly patients. Emerg Med Clin North Am 2018;36(1):219-35.

5. Cavlak M, Akçan R, Tümer AR, et al. Forensic medicine evaluation of alzheimer patients: a series from Ankara, Turkey. Turk J Med Sci 2015;45(5):1047-50.

6. Bonne S, Schuerer DJ. Trauma in the older adult: epidemiology and evolving geriatric trauma principles. Clin Geriatr Med 2013;29(1):137-50. 
7. Frazao SL, Silva MS, Norton P, Magalhaes T. Domestic violence against elderly with disability. J Forensic Leg Med 2014;28:19-24.

8. Gokcelli DK, Tasar PT, Akcam NO, et al. Evaluation of attempted older adults suicides admitted to a university hospital emergency department: Izmir study. Asian J Psychiatr 2017;30:196-9.

9. Reske-Nielsen C, Medzon R. Geriatric trauma. Emerg Med Clin North Am 2016;34(3):483-500.

10. Bilgin NG, Mert E. The characteristics of geriatric forensic cases. Turk J Geriatr 2005;8(1):13-16.

11. Hilal A, Akçan R, Eren A, Turhan A, Arslan M. Forensic geriatric deaths in Adana, Turkey. Arch Gerontol Geriatr 2010;50(3):9-12.

12. Kelsey JL, Procter-Gray E, Hannan MT, Li W. Heterogeneity of falls among older adults: implications for public health prevention. Am J Public Health 2012;102(11):2149-56.

13. Ferrera PC, Bartfield JM, D'Andrea CC. Outcomes of admitted geriatric trauma victims. Am J Emerg Med 2000;18(5):575-80.

14. Pudelek B. Geriatric trauma: special needs for a special population. AACN Clin Issues 2002;13(1):61-72.

15. Byard RW, Hanson KA, Gilbert JD. Suicide methods in the elderly in South Australia 1981-2000. J Clin Forensic Med 2004;11(2):71-4.

16. Akıncı E, Akıllı NB, Koylu R, Cander B. A retrospective evaluation of the patients over 65 years old who treated in toxicology intensive care unit because of unintentional or suicidal poisoning. Turk J Geriatr 2013;16(3):330-4.

17. Adams SD, Holcomb JB. Geriatric trauma. Curr Opin Crit Care 2015;21(6):520-6.

18. Hashmi A, Ibrahim-Zada I, Rhee P, et al. Predictors of mortality in geriatric trauma patients: a systematic review and meta-analysis. J Trauma Acute Care Surg 2014;76(3):894-901.

19. Braun BJ, Holstein J, Fritz T, et al. Polytrauma in the elderly: a review. EFORT Open Rev 2017;1(5):146-51.

20. Giannoudis PV, Harwood PJ, Court-Brown C, Pape HC. Severe and multiple trauma in older patients; incidence and mortality. Injury 2009;40(4):362-7.

21. Cevik Y, Doğan NÖ, Daş M, et al. Evaluation of geriatric patients with trauma scores after motor vehicle trauma. Am J Emerg Med 2013;31(10):1453-6.

22. Hollis S, Lecky F, Yates DW, Woodford M. The effect of pre-existing medical conditions and age on mortality after injury. J Trauma 2006;61(5):1255-60.

23. Clement ND, Tennant $C$, Muwanga C. Polytrauma in the elderly: predictors of the cause and time of death. Scand J Trauma Resusc Emerg Med 2010;18:26. 